Iwona SKORDZKA, Ph. D.

Faculty of Economics and Management, University of Bialystok

e-mail: i.skrodzka@uwb.edu.pl

DOI: $10.15290 /$ ose.2016.05.83.07

\title{
THE SYNTHETIC MEASURE OF THE LEVEL OF SMART GROWTH IN THE EUROPEAN UNION COUNTRIES
}

\begin{abstract}
Summary
The issue of smart growth is a relatively new one, yet it has already been discussed by a few authors. According to the definition proposed by the European Commission, smart growth it is growth based on two pillars: knowledge and innovation. Smart growth is difficult to measure due to its complexity, multidimensionality, unobservability. The aim of the paper is construction of the synthetic measure of the level of smart growth. The research focuses on the 28 European Union countries in 2013.
\end{abstract}

Key words: smart growth, Europe 2020 strategy, European Union, Hellwig's synthetic measure of development

JEL: C38, O11

\section{Introduction}

Recent years have witnessed numerous changes in economic theories, especially with reference to the following concepts [Piech, 2009, pp. x-xi]:

- information society, i.e. the one which uses teleinformation technologies intensively,

- $\quad$ knowledge-based economy (KBE), including 'the new economy' (teleinformation technologies it promotes), issues in education (knowledge society), as well as innovation systems, and the institutional system, which is considered indispensable for the development of the above-mentioned elements.

These concepts were emphasized in the EU programmes such as the Lisbon Strategy and the Europe 2020 Strategy. The Lisbon Strategy stated that "knowledge and innovation are the beating heart of European growth" [Working together..., 2005, p. 4]. The Europe 2020 Strategy, a new long-term European growth programme, which replaced the Lisbon Strategy, stresses the need for a greater coordination of the EU member states in order to overcome the crisis and implement the reforms which will enable to face the challenges of globalization, ageing societies and a growing need for resource efficiency. Therefore, three priorities were determined [Europe 2020..., 2010, p. 8]: 
- $\quad$ smart growth - developing an economy based on knowledge and innovation,

- $\quad$ sustainable growth - promoting a more resource efficient, greener and more competitive economy,

- $\quad$ inclusive growth - fostering a high-employment economy delivering economic, social and territorial cohesion.

According to the definition proposed by the European Commission, smart growth it is growth based on two driving forces: knowledge and innovation. The Commission defines aims whose implementation is supposed to foster smart growth: to improve the quality of education, to improve research, to support transfer of innovations and knowledge inside the EU, to fully use information and communication technologies, and to ensure that innovative ideas are turned into new products and services that can generate growth and jobs and help address social challenges both in Europe and worldwide [Europe 2020 ..., 2010, pp. 9-10]. It also proposed the following main indicators for monitoring smart growth [Europe 2020..., 2010, p. 12]:

- gross domestic expenditure on R\&D (\% of GDP),

- $\quad$ early leavers from education and training (\% of population aged 18-24),

- $\quad$ tertiary educational attainment (\% of population aged $30-34)$.

Smart growth is difficult to measure due to its complexity, multidimensionality, unobservability. Its measurement requires prior solution of various problems such as the imprecise and unquantifiable definition of both smart growth itself and its pillars, the choice of method, the choice of measurements referring to different aspects of smart growth, the choice of an optimal set of indicators including the criterion of information availability and lowering the cost of obtaining such information, data availability.

The aim of the paper is construction of the synthetic measure of the level of smart growth in the European Union countries (EU-28) in 20131. In this study the concept of measurement of smart growth is based on Knowledge Assessment Methodology (KAM) [Chen, Dahlman, 2005], European Innovation Scoreboard (EIS) [Innovation Union..., 2015] and Hellwig's synthetic measure of development (HSMD) [Hellwig, 1968]. The results of the research will be important for regional policy, under which decisions are made about the use of EU funds.

\section{Research method}

Hellwig's synthetic measure of development [Hellwig, 1968] is one of classical methods of linear ordering of multivariate objects (e.g. countries, provinces, municipalities, etc. $)^{2}$. Under this method, the Euclidean distance of each multivariate object from the development pattern is determined. In this method, the following stages can be distinguished:

Stage 1. Selection of indicators basing on substantive and statistical reasons (see paragraph 3).

\footnotetext{
1 The choice of the year was connected with data availability.

2 See other taxonomic methods in [Hwang, Yoon, 1981; Nowak, 1990].
} 
Stage 2. Identification of type of indicators (stimulant, destimulant, nominant). Stage 3. Normalization of the values of indicators.

In this study standardization ${ }^{3}$ was used

$$
z_{i j}=\frac{x_{i j}-\bar{x}_{j}}{s_{j}} \quad(i=1,2, \ldots, n, j=1,2, \ldots, m),
$$

where

$x_{i j}-i$-th value of $j$-th indicator,

$\bar{x}_{j}-$ mean of $j$-th indicator,

$s_{j}-$ standard deviation of $j$-th indicator.

Stage 4. Determination of development pattern $z_{0}=\left[z_{01}, z_{02}, \ldots, z_{0 j}, \ldots z_{0 m}\right]$, where

$$
z_{0 j}=\left\{\begin{array}{ll}
\max _{i} z_{i j}, & \text { if } z_{i j} \text { variable is a stimulant } \\
\min _{i} z_{i j}, & \text { if } z_{i j} \text { variable is a destimulant }
\end{array} .\right.
$$

Stage 5. Calculation of the Euclidean distance of $i$-th object from the development pattern

$$
d_{i 0}=\sqrt{\sum_{j=1}^{m}\left(z_{i j}-z_{0 j}\right)^{2}} \quad(i=1,2, \ldots, n)
$$

Stage 6. Determination of the value of synthetic measure of development for $i$-th object

$$
m_{i}=1-\frac{d_{i 0}}{d_{0}} \quad(i=1,2, \ldots, n),
$$

where

$$
\begin{gathered}
d_{0}=\bar{d}_{0}+2 s_{0}, \\
\bar{d}_{0}=\frac{1}{n} \sum_{i=1}^{n} d_{i 0}, \\
s_{0}=\sqrt{\frac{1}{n} \sum_{i=1}^{n}\left(d_{i 0}-\bar{d}_{0}\right)^{2}} .
\end{gathered}
$$

Stage 7. Linear ordering of objects according to the values of synthetic measure.

HSMD has the following properties:

- $\quad$ usually takes values in the range $[0,1]$, but in some cases it may take negative values and this means that the analyzed object is definitely worse than others [Nowak, 1990, p. 89; Zeliaś, 2000, p. 93],

- measure value for the pattern is 1 ,

- the higher level of a complex phenomenon, the higher value of measure of development [Zeliaś, 2000, p. 41].

\section{Indicators of the level of smart growth}

The selection of indicators was based on substantive and statistical reasons. Two types of research was used as the substantive reason: Knowledge Assessment Methodology (World Bank) and European Innovation Scoreboard (European Commission).

\footnotetext{
${ }^{3}$ See other methods in [Handbook of construction..., 2008, pp. 83-85].
} 
The KAM, which was developed within the framework of The Knowledge for Development (K4D) programme, is regarded as the most developed way of measuring KBE. It distinguishes four key pillars [Chen, Dahlman, 2005, p. 33]:

- Economic Incentive and Institutional Regime, responsible for developing economic policy and the work of institutions. Extending, disseminating and using knowledge by these entities is supposed to ensure effectiveness by an adequate division of resources and by boosting creativity. Indicators: tariff and non-tariff barriers, regulatory quality, rule of law.

- Education and Human Resources, which means personnel who can adopt to constantly developing technological solutions thanks to upgrading their skills. Indicators: adult literacy rate (\% age 15 and above) latest version - average years of schooling, secondary enrollment, tertiary enrollment.

- Innovation System, which involves the activities of economic entities, research centres, universities, advisory bodies and other organizations whose operations are adjusted to preferences of more and more demanding customers. Indicators: researchers in $\mathrm{R} \& \mathrm{D}$, per million population or in the latest version: payments and income from licence fees, patents applications granted by the US Patent and Trademark Office, per million population, scientific and technical journals articles, per million population.

Information Infrastructure, which ensures effective communication and faster transfer of data. All these aspects influence transfer of information and knowledge. The measurements applied: telephones per 1000 population (telephone mainlines and mobile phones), computers per 1000 population, Internet users per 10000 population. The pillars are used to construct two global indexes [Chen, Dahlman, 2005, pp. 9-13]:

- Knowledge Index (KI), which determines the knowledge potential of a country; this indicator is calculated as an arithmetic average of three subindexes, which represent three pillars of KAM (except the Economic Incentive and Institutional Regime),

- Knowledge Economy Index (KEI), which determines a general development level of a knowledge-based economy; this indicator is calculated as an arithmetic average of four subindices, which represent the four pillars of KAM.

The advantages of this method are simplicity, clarity, and versatility. It enables comparison of the KI and KEI indicators and their components in both dimensions: intertemporal and international. The method is criticised inter alia for [Becla, 2010, pp. 56-70]:

- insufficient theoretical background,

- the tendency to repeat information by indicators,

- $\quad$ the lack of differentiated weights for indicators,

- insufficient information about many of the analyzed economies,

- inaccessibility of indicators in the systems of international statistics,

- $\quad$ incomparability of data due to a variety of data sources.

Among numerous methods of innovation measurement, the most advanced and the most popular one with economists is the European Commission method, used since 2000 in the reports of the European Innovation Scoreboard (EIS). The EIS Table of 
2015 is based on 25 indicators concerning scientific research and innovation and includes 28 EU member states, South Korea, USA, Japan, Canada, Australia and the BRICS countries. The indicators are divided into three main dimensions [Innovation Union..., 2015, pp. 7-8]:

- $\quad$ enablers, i.e. basic elements enabling innovation to emerge (human resources, finance and support, open excellent and research systems),

- firm activities capturing innovation performance of European firms (investments, linkage and entrepreneurship, intellectual assets),

- $\quad$ outputs capturing the ways in which innovations turn into economic benefits (innovators, economic effects).

The EIS approach is criticized inter alia for [Hollanders, van Cruysen, 2008, pp. 9-10]:

- a too statistical (correlation) approach to innovation instead of relying on a model of innovation, which means that the method is lacking in theoretical basis,

- $\quad$ too much concentration on high technologies, while innovation may occur irrespective of the intensity of research and development,

- co-linearity - some indicators are correlated, as a result of which the method is focused on $\mathrm{R} \& \mathrm{D}$,

- problems with identification of stimulants - it is not always the case that a higher indicator is beneficial for general innovation,

- problems with data availability and completeness.

In this study the initial set contained 37 indicators: 12 from KAM methodology and 25 from EIS methodology. The lack of data was the reason for the rejection of 14 indicators. For the other 23 indicators the level of diversity was examined (the critical value of the coefficient of variation was set at $10 \%$ ). Moreover to eliminate from the set of indicators those variables which are too strongly correlated with other variables, Hellwig's parametric method was used (the critical value of the coefficient of correlation was set at 0,7$)$. The final set of indicators presents table 1 . Eight of them (from 1 to 8) belong to EIS methodology, one is from KAM methodology (No. 9).

Table 2 contains the basic descriptive statistics of indicators of the level of smart growth. The highest variation relates to indicator "Community trademarks per billion GDP (in PPS)" (IA_2.3.3 - 102\%), the lowest - to indicator "Percentage population aged 30-34 having completed tertiary education” (HR_1.1.2 - 24.7\%). Two indicators "Community trademarks per billion GDP (in PPS)" (IA_2.3.3) and „Sales of new to market and new to firm innovations as percentage of turnover" (EE_3.2.4) have achieved the lowest value for Romania. Ireland was characterized by the highest values of two indicators: "Percentage population aged 30-34 having completed tertiary education" (HR_1.1.2) and "Knowledge-intensive services exports as percentage of total service exports”EE_3.2.3. 
TABLE 1.

Indicators of the level of smart growth

\begin{tabular}{|c|c|l|c|c|}
\hline No. & Symbol & \multicolumn{1}{|c|}{ Indicator } & Source & Type \\
\hline 1 & HR_1.1.2 & $\begin{array}{l}\text { Percentage population aged 30-34 having } \\
\text { completed tertiary education }\end{array}$ & Eurostat & Stimulant \\
\hline 2 & HR_1.1.3 & $\begin{array}{l}\text { Percentage youth aged 20-24 having attained at } \\
\text { least upper secondary level education }\end{array}$ & Eurostat & Stimulant \\
\hline 3 & FI_2.1.2 & $\begin{array}{l}\text { Non-R\&D innovation expenditures as } \\
\text { percentage of turnover }\end{array}$ & $\begin{array}{c}\text { Eurostat } \\
\text { (CIS) }\end{array}$ & Stimulant \\
\hline 4 & LE_2.2.2 & $\begin{array}{l}\text { Innovative SMEs collaborating with others } \\
\text { as percentage of SMEs }\end{array}$ & $\begin{array}{c}\text { Eurostat } \\
\text { (CIS) }\end{array}$ & Stimulant \\
\hline 5 & IA_2.3.3 & $\begin{array}{l}\text { Community trademarks per billion GDP } \\
\text { (in Purchasing Power Standard) }\end{array}$ & $\begin{array}{c}\text { Eurostat } \\
\text { Stimulant }\end{array}$ & Sting \\
\hline 7 & EE_3.2.3 & $\begin{array}{l}\text { Knowledge-intensive services exports as } \\
\text { percentage of total service exports }\end{array}$ & $\begin{array}{c}\text { Eurostat } \\
\text { (CIS) }\end{array}$ & Stimulant \\
\hline 8 & EE_3.2.4 & $\begin{array}{l}\text { Sales of new to market and new to firm } \\
\text { innovations as percentage of turnover }\end{array}$ & $\begin{array}{c}\text { Eurostat } \\
\text { (CIS) }\end{array}$ & Stimulant \\
\hline 9 & KAM_9 & $\begin{array}{l}\text { Scientific and Technical Journal Articles per } \\
\text { million inhabitants }\end{array}$ & $\begin{array}{c}\text { World } \\
\text { Bank }\end{array}$ & Stimulant \\
\hline
\end{tabular}

Source: own elaboration.

Basic descriptive statistics of indicators

\begin{tabular}{|c|c|c|c|c|c|c|}
\hline No. & Symbol & $\begin{array}{l}\text { Minimu } \\
\text { value }\end{array}$ & $\begin{array}{l}\text { Maximum } \\
\text { value }\end{array}$ & Mean & $\begin{array}{l}\text { Standard } \\
\text { deviation }\end{array}$ & $\begin{array}{c}\text { Coefficient } \\
\text { of variation } \\
(\%)\end{array}$ \\
\hline 1 & HR_1.1.2 & $\begin{array}{l}22.5 \\
\text { Italy }\end{array}$ & $\begin{array}{l}52.6 \\
\text { Ireland }\end{array}$ & 37.9 & 9.4 & 24.7 \\
\hline 2 & HR_1.1.3 & $\begin{array}{l}41.9 \\
\text { Spain }\end{array}$ & $\begin{array}{c}86.9 \\
\text { Croatia }\end{array}$ & 68.4 & 10.6 & 15.5 \\
\hline 3 & FI_2.1.2 & $\begin{array}{c}0.14 \\
\text { Luxembourg }\end{array}$ & $\begin{array}{c}1.55 \\
\text { Estonia }\end{array}$ & 0.68 & 0.37 & 55.1 \\
\hline 4 & LE_2.2.2 & $\begin{array}{l}12.7 \\
\text { Italy } \\
\end{array}$ & $\begin{array}{c}66.7 \\
\text { United Kingdom }\end{array}$ & 34.6 & 12.3 & 35.6 \\
\hline 5 & IA_2.3.3 & $\begin{array}{c}1.6 \\
\text { Romania }\end{array}$ & $\begin{array}{c}37.1 \\
\text { Malta }\end{array}$ & 7.9 & 8.1 & 102 \\
\hline 6 & IN_3.1.2 & $\begin{array}{c}6.8 \\
\text { Netherlands }\end{array}$ & $\begin{array}{l}18.2 \\
\text { Greece }\end{array}$ & 12.8 & 3.2 & 25.3 \\
\hline 7 & EE_3.2.3 & $\begin{array}{c}14.2 \\
\text { Lithuania }\end{array}$ & $\begin{array}{l}77.0 \\
\text { Ireland }\end{array}$ & 40.6 & 16.4 & 40.5 \\
\hline 8 & EE_3.2.4 & $\begin{array}{c}3.7 \\
\text { Romania }\end{array}$ & $\begin{array}{c}19.6 \\
\text { Slovakia }\end{array}$ & 10.3 & 3.6 & 34.6 \\
\hline 9 & KAM_9 & $\begin{array}{c}367.5 \\
\text { Bulgaria }\end{array}$ & $\begin{array}{c}2228.0 \\
\text { Denmark }\end{array}$ & 1194.5 & 462.0 & 38.7 \\
\hline
\end{tabular}

Source: own elaboration. 


\section{The level of smart growth in the European Union countries in 2013}

Table 3 contains the values of synthetic measure of the level of smart growth for 28 European Union countries in 2013.

TABLE 3.

Values of synthetic measure of the level of smart growth in 2013

\begin{tabular}{|c|c|c|}
\hline No. & Country & Value of synthetic measure \\
\hline 1 & Denmark & 0.345 \\
\hline 2 & United Kingdom & 0.330 \\
\hline 3 & Cyprus & 0.325 \\
\hline 4 & Greece & 0.306 \\
\hline 5 & Slovenia & 0.286 \\
\hline 6 & Germany & 0.284 \\
\hline 7 & Estonia & 0.272 \\
\hline 8 & Luxembourg & 0.255 \\
\hline 9 & Ireland & 0.247 \\
\hline 10 & Finland & 0.245 \\
\hline 11 & Austria & 0.239 \\
\hline 12 & Belgium & 0.237 \\
\hline 13 & Sweden & 0.228 \\
\hline 14 & Slovakia & 0.224 \\
\hline 15 & France & 0.212 \\
\hline 16 & Czech Republic & 0.196 \\
\hline 17 & Hungary & 0.169 \\
\hline 18 & Lithuania & 0.150 \\
\hline 19 & Malta & 0.147 \\
\hline 20 & Croatia & 0.140 \\
\hline 21 & Netherlands & 0.132 \\
\hline 22 & Portugal & 0.113 \\
\hline 23 & Poland & 0.099 \\
\hline 24 & Latvia & 0.098 \\
\hline 25 & Italy & 0.093 \\
\hline 26 & Spain & 0.090 \\
\hline 27 & Romania & -0.013 \\
\hline 28 & Bulgaria & -0.035 \\
\hline \multicolumn{2}{|c|}{ Mean } & 0.193 \\
\hline \multicolumn{2}{|c|}{ Standard deviation } & 0.1 \\
\hline
\end{tabular}

Source: own elaboration. 
The synthetic measure achieves value of 1 for the pattern. Moreover the higher value of synthetic measure, the higher level of smart growth. The results shows that the level of smart growth in the EU-28 countries was not very high in 2013 . The mean value of synthetic measure of smart growth level was 0.193 , while standard deviation -0.1 . The highest value was 0.345 (Denmark) and two countries have achieved negative values (Romania, Bulgaria).

The positions of the countries in the ranking of smart growth level ware connected with the values of indicators. In the table 4 are presented the rankings of the countries in terms of the value of each indicator as well as in terms of the value of synthetic measure (HSMD).

TABLE 4.

Scoreboard of the level of smart growth in 2013

\begin{tabular}{|c|c|c|c|c|c|c|c|c|c|c|}
\hline Country & 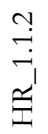 & 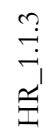 & $\frac{\sim}{i}$ & 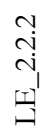 & 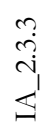 & $\begin{array}{l}\stackrel{\sim}{Z} \\
\ddot{B} \\
Z\end{array}$ & 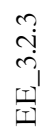 & $\begin{array}{l}\stackrel{+}{\sim} \\
\stackrel{\sim}{\sim} \\
\stackrel{T}{\mid I}\end{array}$ & $\sum_{\underline{\Sigma}}^{\stackrel{\delta}{5}}$ & 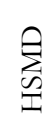 \\
\hline Denmark & 9 & 18 & 21 & 8 & 7 & 15 & 3 & 4 & 1 & 1 \\
\hline United Kingdom & 6 & 26 & 25 & 1 & 14 & 5 & 4 & 3 & 6 & 2 \\
\hline Cyprus & 5 & 25 & 15 & 2 & 3 & 17 & 9 & 11 & 19 & 3 \\
\hline Greece & 17 & 11 & 8 & 11 & 24 & 1 & 5 & 10 & 18 & 4 \\
\hline Slovenia & 16 & 2 & 18 & 4 & 13 & 11 & 25 & 15 & 5 & 5 \\
\hline Germany & 18 & 16 & 3 & 23 & 9 & 18 & 6 & 7 & 13 & 6 \\
\hline Estonia & 12 & 14 & 1 & 6 & 5 & 23 & 11 & 22 & 17 & 7 \\
\hline Luxembourg & 2 & 21 & 28 & 24 & 2 & 2 & 2 & 20 & 10 & 8 \\
\hline Ireland & 1 & 19 & 20 & 18 & 12 & 4 & 1 & 21 & 7 & 9 \\
\hline Finland & 7 & 3 & 22 & 13 & 10 & 26 & 8 & 13 & 3 & 10 \\
\hline Austria & 22 & 4 & 19 & 7 & 4 & 7 & 24 & 18 & 9 & 11 \\
\hline Belgium & 11 & 23 & 13 & 3 & 16 & 24 & 10 & 12 & 8 & 12 \\
\hline Sweden & 4 & 17 & 10 & 19 & 6 & 20 & 12 & 24 & 2 & 13 \\
\hline Slovakia & 23 & 7 & 9 & 10 & 26 & 12 & 20 & 1 & 21 & 14 \\
\hline France & 8 & 22 & 23 & 15 & 21 & 3 & 13 & 5 & 16 & 15 \\
\hline Czech Republic & 24 & 5 & 11 & 12 & 22 & 25 & 15 & 6 & 11 & 16 \\
\hline Hungary & 19 & 8 & 12 & 9 & 25 & 6 & 22 & 19 & 24 & 17 \\
\hline Lithuania & 3 & 10 & 5 & 5 & 19 & 13 & 28 & 25 & 23 & 18 \\
\hline Malta & 25 & 24 & 4 & 27 & 1 & 8 & 26 & 16 & 25 & 19 \\
\hline Croatia & 26 & 1 & 7 & 14 & 27 & 16 & 27 & 17 & 20 & 20 \\
\hline Netherlands & 10 & 20 & 27 & 16 & 11 & 28 & 19 & 9 & 4 & 21 \\
\hline Portugal & 20 & 27 & 14 & 25 & 18 & 14 & 17 & 8 & 12 & 22 \\
\hline Poland & 15 & 9 & 6 & 17 & 20 & 27 & 16 & 23 & 22 & 23 \\
\hline Latvia & 14 & 12 & 2 & 21 & 23 & 19 & 14 & 26 & 26 & 24 \\
\hline Italy & 28 & 13 & 16 & 28 & 15 & 9 & 18 & 14 & 15 & 25 \\
\hline Spain & 13 & 28 & 24 & 20 & 8 & 21 & 21 & 2 & 14 & 26 \\
\hline Romania & 27 & 15 & 26 & 22 & 28 & 10 & 7 & 28 & 27 & 27 \\
\hline Bulgaria & 21 & 6 & 17 & 26 & 17 & 22 & 23 & 27 & 28 & 28 \\
\hline
\end{tabular}

Source: own elaboration. 
The results inconsistent with the expectations are: low position of Sweden in the scoreboard and high positions of Cyprus and Greece. Usually, Sweden is in the top of the rankings related to the economic development, while Cyprus and Greece - in the middle. This results can be related with the lack of indicators of economic development among indicators of the level of smart growth. Sweden took low positions in terms of the following indicators: EE_3.2.4 (24 position), IN_3.1.2 (20 position), LE_2.2.2 (19 position). Cyprus achieved a high position in terms of the following indicators: LE_2.2.2 (2 position), IA_2.3.3 (3 position), HR_1.1.2 (5 position), and Greece in terms of the following indicators: IN_3.1.2 (1 position) and EE_3.2.3 (5 position).

\section{Conclusions}

The issue of smart growth is a relatively new one, yet it has already been discussed by a few authors [Markowska, Strahl, 2012; Bal-Domańska, 2013; Strahl, 2014; Sobczak, 2014]. Nevertheless, studies on this topic are scarce. Their authors unanimously agree that there is a need for detailed theoretical and empirical research. The pillars of smart growth, i.e. knowledge and innovation, have been broadly discussed in literature, both in Poland and abroad [Gospodarka oparta na..., 2007; Piech, 2009; Gospodarka oparta na..., 2011; Chen, Dahlman, 2005; Hollanders, van Cruysen, 2008], yet there is no consent as to the method of defining and measuring them.

The research presented in the paper are the author's first attempt to measure the level of smart growth of the European Union countries. However, they may provide a starting point for future work.

\section{References}

Bal-Domańska B., 2013, Does Smart Growth Enhance Economic Cohesion? An Analysis by the Level of Research and Development Activities Intensity, Prace Naukowe Uniwersytetu Ekonomicznego we Wrocławiu, No. 286, Wrocław.

Becla A., 2010, Wady $i$ zalety metody KAM (Knowledge Assessment Methodology) stużqcej do identyfikacji poziomu zaawansowania gospodarki opartej na wiedzy, Prace Naukowe Uniwersytetu Ekonomicznego we Wrocławiu, No. 139, Wrocław.

Chen D. H. C., Dahlman C. J., 2005, The Knowledge Economy, the KAM Methodology and World Bank Operations, World Bank Institute, http://siteresources.worldbank.org/ INTUNIKAM/Resources/2012.pdf (accessed: 19.05.2016).

Europe 2020. A European Strategy for Smart, Sustainable and Inclusive Growth, 2010, European Commission, Brussels.

Gospodarka oparta na wiedzyy, 2007, (ed.) W. Welfe, Państwowe Wydawnictwo Ekonomiczne, Warszawa.

Gospodarka oparta na wiedzy, 2011, (ed.) B. Poskrobko, Wydawnictwo Wyższej Szkoły Ekonomicznej w Białymstoku, Białystok. 
Handbook on Constructing Composite Indicators. Methodology and User Guide 2008, OECD, http://www.oecd.org/std/42495745.pdf (accessed: 07.11.2016).

Hellwig Z., 1968, Zastosowanie metody taksonomicznej do typologicznego podziatu krajón ze wagledu na poziom rozwoju i strukture wykwalifikowanych kadr, „Przeglad Statystyczny”, Z. 4.

Hollanders H, van Cruysen A. 2008, Retbinking the European Innovation Score-Board: A New Methodology for 2008-2010, PRO INNO/INNO Metrics.

Hwang C. L., Yoon K., 1981, Multiple Attribute Decision-Making: Methods and Applications, Springer-Verlag, Berlin - Heidelberg - New York.

Innovation Union Scoreboard 2015, 2015, European Commission, Brussels.

Markowska M., Strahl D., 2012, European Regional Space Classification Regarding Smart Growth Level, „Comparative Economic Research. Central and Eastern Europe”, No. 4.

Nowak E., 1990, Metody taksonomicżne w klasyfikacii obiektón spoteczno-gospodarcsych, Państwowe Wydawnictwo Ekonomiczne, Warszawa.

Piech K., 2009, Wiedza i innowacje w rozwoju gospodarczym: w kierunku pomiaru i wspótczesnej roli państwa, Instytut Wiedzy i Innowacji, Warszawa.

Sobczak E., 2014, Harmonijność inteligentnego rozpwoju regionón Unii Europejskiej, Prace Naukowe UE we Wrocławiu, No. 328, Wrocław.

Strahl D., 2014, Klasyfikacja europejskiej przestrzeni regionalnej ze wagledu na filary inteligentnego rozpoju z. wy korsystaniem referencyjnego systemu granicznego, Prace Naukowe Uniwersytetu Ekonomicznego we Wrocławiu, No. 327, Wrocław.

Working Together for Growth and Jobs - A New Start for the Lisbon Strategy, 2005, Communication to the Spring European Council, European Commission, Brussels.

Zeliaś A., 2000, Taksonomiczna analiza pržestržennego zróżnicowania poziomu życia w Polsce w ujeciu dynamicznym, Wydawnictwo Akademii Ekonomicznej w Krakowie, Kraków. 